\title{
Skjult i reolen
}

Peter Marcussens papirer fra besættelsestiden genfundet på Fyn

\section{af Thomas Toftegård Knudsen}

I en gammel reol på Fyn blev der i 1993 fundet en bunke papirer. Ved en omhyggelig gennemgang blev det klart, at de var en hilsen fra besættelsesårene og Det unge Grænseværn/Dansk Nordisk Ungdomsforbund. Stud. mag. Thomas Toftegård Knudsen, Odense, fortæller her den spændende historie.

I efteråret 1993 blev der på Fyn gjort et bemærkelsesværdigt fund af fortrolige papirer fra den tyske besættelse af Danmark 1940-45. Papirerne, hvis antal og fundomstændighed var højst usædvanlig, viste sig at høre hjemme i Sønderjylland - nærmere bestemt i Gråsten.

Der er tale om dokumenter med tilknytning til organisationen Det Unge Grænseværn og dens formand, lærer Peter Marcussen, hvis virke i 1930rne og 40rne udgik fra Folkunghus i Gråsten.

De mange papirer lå skjult $i$ et hulrum i toppen af en reol, der var efterladt i den nu nedrevne Svennekærgård på det militære øvelsesområde i Højstrup ved Odense. En ansat ved det firma, der skulle forestå saneringen, ingeniør Poul Jensen fra Hudevad, fik umiddelbart før nedrivningen sat den forladte reol til side og havde efterfølgende transporteret den hjem. Efter nogle måneder fik Poul Jensen set nærmere på det gamle møbel og afdækkede dets hemmelighed.

De fundne papirer blev overdraget til Stadsarkivet i Odense, som har udarbejdet en registratur. Materialet vil nu vende tilbage til Gråsten, hvor det vil være tilgængeligt på kommunens lokalarkiv $\mathrm{i}$ henhold til de almindelige tilgængelighedsregler.

Det må anses som et rent lykketræf, at papirerne blev reddet for eftertiden og igen så dagens lys efter at have været gemt og glemt $\mathrm{i}$ mere end 50 år. Hvorledes Peter Marcussens papirer er endt på Svennekærgård, kan der kun gisnes om, men placeringen i den gamle reol har uden tvivl haft til formål at forhindre den tyske besættelsesmagt $\mathrm{i}$ at få indsigt $\mathrm{i}$ Marcussens private korrespondance og detaljer vedrørende foreningen Det Unge Grænseværn. 


\section{Det Unge Grænseværn}

I månederne efter Hitlers nationalsocialistiske magtovertagelse i Tyskland den 30. januar 1933 blev der hos de tysk-nationale slesvig-holstenske lokalpolitikere givet næring til det gamle krav om et udelt Slesvig-Holsten, det selvsamme krav Danmark med magt havde afvist med krigen i 1848-50. Ved talrige møder i Slesvig-Holsten blev der i forårsmånederne 1933 sat fokus på den dansktyske grænse fra 1920, og kravet om en revision af grænsen blev til stadighed skærpet.

Et $\mathrm{i}$ denne forbindelse ofte anvendt citat fra dr. Sievers, formanden for Schleswig-Holsteiner Bund, understreger, med hvilken skarphed grænserevisionskravet blev fremsat: "Vi må klart og iskoldt sige danskerne, hvad vi vil. Vi vil have Nordslesvig igen. Begriber danskerne ikke, at grænsen må revideres, kan det tidspunkt komme, hvor der med kendsgerningernes magt træffes en afgørelse, som ikke passer danskerne, men som det enige Slesvig-Holstens vilje bestemmer«. Det var næppe tilfældigt, at dr. Sievers havde valgt at holde sin tale netop den 24. marts 1933, på 85-årsdagen for den slesvig-holstenske opstand mod Danmark.

Sønderjyderne var særligt opmærksomme på de barske udtalelser sydfra, og der blev ved flere møder $i$ landsdelen taget initiativ til at imødegå den nationalsocialistiske propaganda. Mest synlige af disse initiativer var de sønderjydske ungdomsorganisationers to store gymnastikstævner i 1933 i Tønder og i skanserne ved Dybbøl, hvor sidstnævnte stævne samlede hen ved 40.000 deltagere. Stævnerne havde til formål at vise udadtil, at den sønderjydske ungdom på tværs af alle skel havde én fællesnævner - danskheden. Det var med baggrund $i$ den danske ungdoms behov for at danne en kulturel barriere mod den tyske nationalsocialisme, at blandt andet Peter Marcussen tog initiativet til at danne foreningen Det Unge Grænseværn.

Foreningen Det Unge Grænseværn (D.U.G.) opnåede hurtigt stor udbredelse. Efter at foreningen i 1934 blev omdannet til landsforening, steg medlemstallet fra ca. 9.000 personlige medlemmer samt 254 kollektivt indmeldte foreninger i 1935 til at omfatte over 30.000 personlige medlemmer og et ukendt antal foreninger i $1940 .{ }^{1}$ Målet for D.U.G. er kortest beskrevet ved at citere foreningens formålsparagraf: »Det Unge Grænseværn er en sammenslutning af dansk ungdom (fællesorganisationer, foreninger og enkeltpersoner) til fælles værn om og styrkelse af dansk-nordisk ånds- og kulturliv i grænselandet «. Indsatsen for at styrke den danske kultur blev spredt ud over en bred front. D.U.G.'s aktiviteter omfattede blandt andet tilskudsordninger til fremskaffelse af foredragsholdere, økonomisk støtte til projekter og foreninger, organisering af sommer- og arbejdslejre i foreningens ejendomme og igangsættelse af aktiviteter, hvor en 


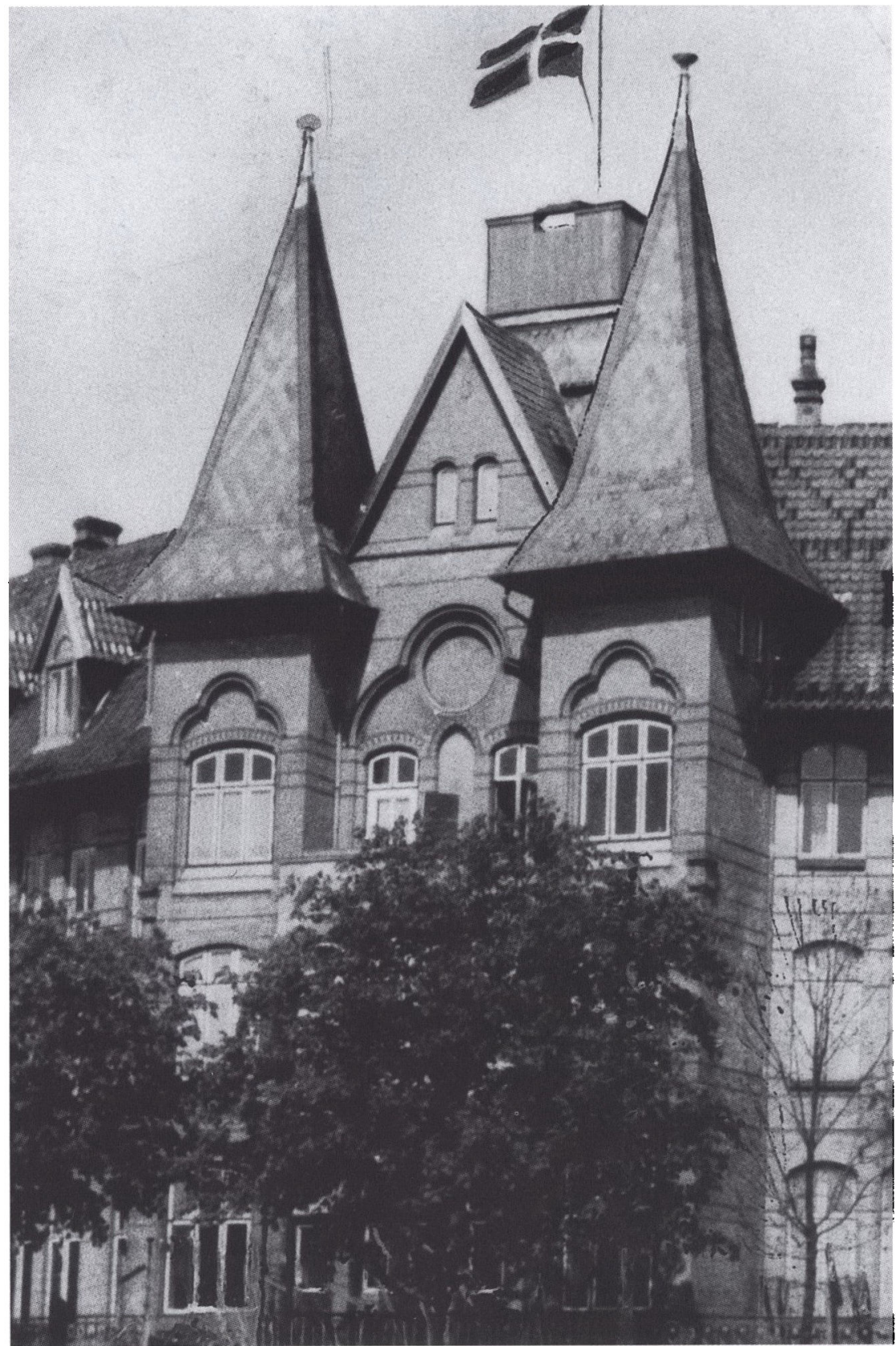

Folkunghus i Gråsten, hvor Det Unge Gransevarns hovedkontor havde til huse i perioden 1939-1953. Her fotograferet den 5. maj 1945. Foto: Kirsten Madsen Hjelmgaard. Privateje. 


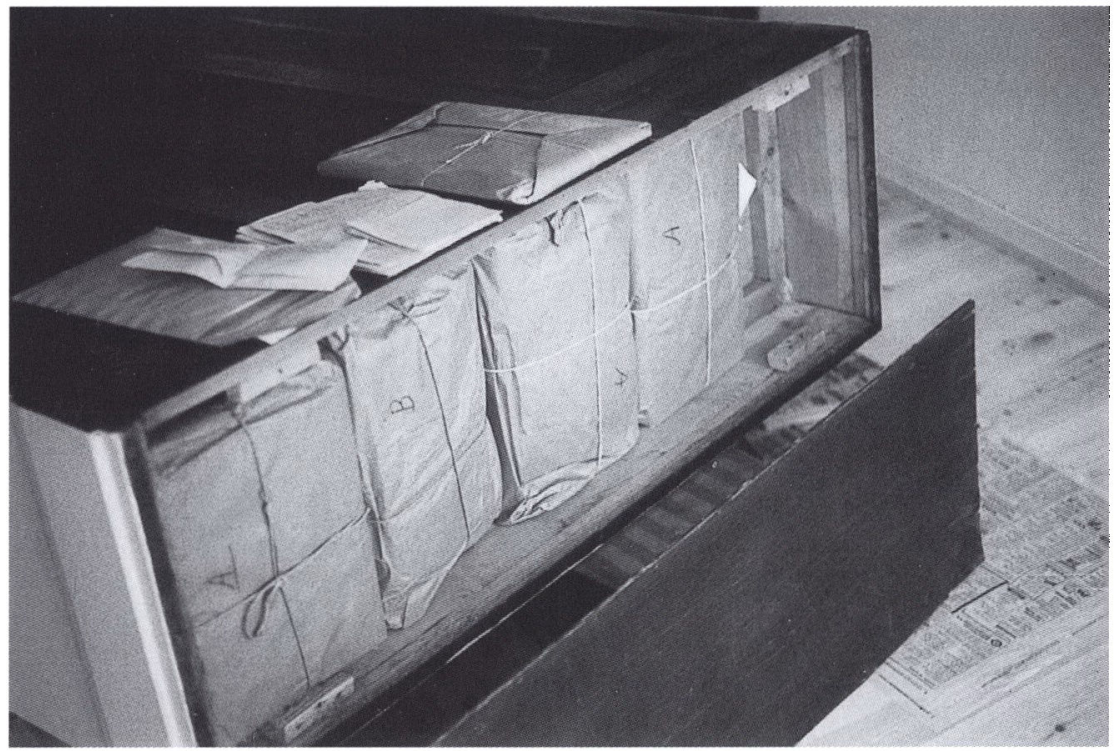

Reolen fra Svennekargård på Fyn med det hemmelige rum, der skjulte Peter Marcussens papirer. Foto: Poul Jensen, 1993.

dansk indsats ikke fandtes eller var for svag. Som igangsættere havde D.U.G. ansat to "vandrelærere«, der rejste rundt i grænseområdet og underviste den sønderjydske ungdom $\mathrm{i}$ gymnastik, folkedans, sange og sanglege, håndarbejde, vævning m.m.

\section{De fundne papirer}

Papirerne, som blev fundet $\mathrm{i}$ reolen på Fyn, omfatter ca. $1 / 2$ hyldemeter. Størstedelen består af trykt illegalt materiale i form af illegale tidsskrifter, arbejdspapirer henvendt til D.U.G.'s tillidsmænd, illegale publikationer, illegale artikler samt forarbejder til disse, afskrifter af forskellige offentlige institutioners interne papirer m.m. Der er tale om en ganske omfattende samling af illegale blade, i alt knap 100 eksemplarer af 19 forskellige tidsskrifter, alle fra perioden sommeren 1943 til august 1944. Derudover gemte reolen en del af P. Marcussens private korrespondance med 41 forskellige personer. Brevene er med tre undtagelser alle dateret i perioden februar 1942 til februar 1944. Yderligere var der blandt indholdet en række legalt trykte publikationer, overvejende fra Folkung-forlaget. For et detaljeret indblik i papirernes indhold kan henvises til den registratur, der opbevares sammen med papirerne på Graasten 
Kommunes Lokalhistoriske Arkiv, samt på Landsarkivet for Sønderjylland i Åbenrå.

Ved et nærmere gennemsyn af materialet fremgår det, at fællesnævneren ud over Peter Marcussen er forlaget Folkung og den virksomhed, der var knyttet til denne afdeling af D.U.G.s organisation. Med virkning fra den 1. januar 1936 oprettedes der inden for D.U.G. en særlig oplysnings- og organisationsafdeling med Marcussen som leder. Målet var dels at få oprettet et særligt grænsearkiv og dels at udgive et kultur- og grænsepolitisk tidsskrift. Begge initiativer havde til hensigt at fremme kendskabet til de grænsepolitiske forhold $\mathrm{i}$ almindelighed. Arkivet, der i 1939 blev flyttet fra Tønder til hovedkontoret i Gråsten, gik tabt, da de ansatte i forbindelse med besættelsen i 1940 ødelagde D.U.G.'s arkiver. Folkung-bladet og det tilhørende Folkung-forlag, derimod, fortsatte i aktivt virke under hele besættelsen, om end man ikke undgik den skarpe tyske censur. Således bortcensureredes hele Det Unge Grænseværns årbog for 1943. Ud over Marcussen var det redaktør Kai Edvard Larsen fra Sønderborg, der sørgede for udgivelsen af Folkung-bladet.

De fundne papirer er øjensynligt et produkt af Marcussens virke som leder af Folkung-forlaget. De knytter sig ikke direkte til redaktionen af bladet eller udgivelsen af forlagets publikationer, men er snarere en del af den almindelige orientering og kontakt udadtil, som enhver redaktør må have. Ud over de mange illegale blade findes der i materialet en lang række nordiske avisartikler, arbejdspapirer m.m., som blandt andet giver oplysninger om de tyske besættelsestropper i Norge, krigen i Finland, begivenhederne i Danmark den 29. august 1943, udskrifter af radioaflytning fra BBC o.s.v. Altsammen materiale, der er fyldt med informationer, der klart afspejler, hvor Marcussen stod placeret $\mathrm{i}$ forhold til den tyske besættelsesmagt.

Naturligvis blev sådanne willegale« informationer ikke gengivet i D.U.G.'s udgivelser. Men det fremgår klart af papirerne, at Marcussen enten uofficielt i D.U.G.-regi eller for egen regning har sammenskrevet, kopieret og sandsynligvis også distribueret disse »illegale« data. Der findes i materialet seks eksempler på sådanne hjemmelavede hefter, hvoraf flere findes i mere end et eksemplar. Det kan således med sikkerhed påvises, at Peter Marcussen aktivt tog del $\mathrm{i}$ illegal oplysningsvirksomhed, om end omfanget synes at have været forholdsvis beskedent.

At papirerne fra Svennekærgård har haft tilknytning til Marcussens hverv som leder af Folkung-forlaget, fremgår også af en del af hans korrespondance. Mange af brevene indeholder tilsendte manuskripter, artikler eller kommentarer af redaktionel karakter, og disse er tydeligvis henvendt til redaktøren Peter Marcussen. Det gælder dog for korrespondancen i modsætning til det trykte materiale, at den ikke udelukkende knytter sig til D.U.G.'s forlagsvirksomhed. 


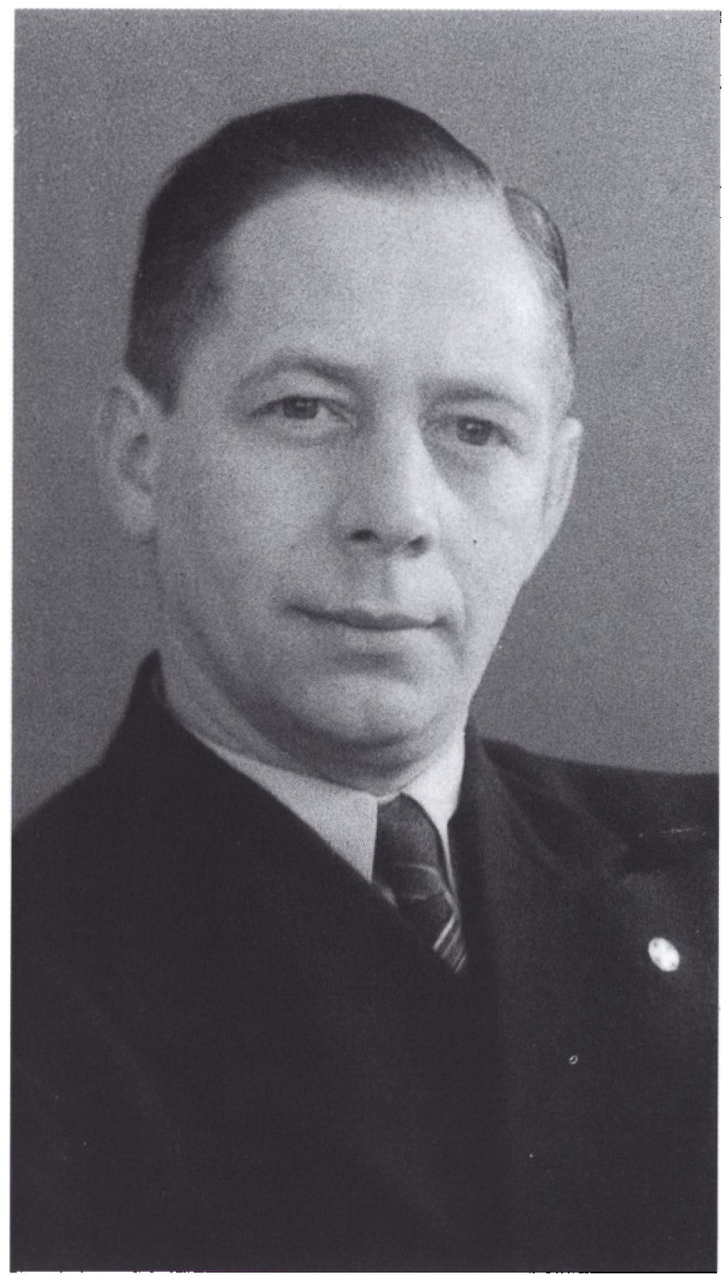

Peter Marcussen (1898-1979) $i$ hans tid som formand for Det Unge Gransevern (1933-1950). Privateje.

Den rummer således dele af Peter Marcussens private breve, samt breve tilstillet Peter Marcussen i hans egenskab af formand for D.U.G.

\section{Grænseværn og skandinavisme}

Af de forskellige henvendelser til Marcussen som formand for D.U.G. er det værd at bide mærke i de breve, der indeholder bemærkninger om D.U.G.'s navneskifte 20. april 1940, hvor foreningen blev omdøbt til Dansk-nordisk Ungdomsforbund (D.N.U.). Navneskiftet var en milepæl i D.U.G.'s historie, 
og samtidig er det en begivenhed, der i eftertiden er blevet opfattet som afslutningen på den periode, hvor foreningen primært var knyttet til Sønderjylland. Marcussen, der personligt stod bag navneskiftet, ønskede at D.U.G.s arbejde i højere grad skulle associeres med den skandinavistiske ideologi, der for ham var hjørnestenen i bestræbelserne på at neutralisere den tysk-nazistiske aggression i Nordslesvig.

Som han så det, var det foruroligende ikke så meget de tyske (slesvigholstenske) trusler om grænseflytning som den fare, der lå i nazismen, i dens besnærende nordisk-germanske »ideologi (den stadige tale om Aufnordung, om "det nordiske menneskes førende rolle i det nye Europa" osv.), endvidere dens kyniske udnyttelse af såvel menneskers politiske naivitet som magtbegær og dens næsten hypnotiske magt til på forhånd at lamme ængstelige og svage sjæle. D.U.G. skulle dels bryde denne magt og forhindre den $i$ at få tag $i$ de naive, de utilfredse, de økonomisk og nationalt svage, dels - og fremfor alt over for nazismens "nordiske idé« stille en nordisk realitet: Vort fællesskab med det øvrige Norden i kultur, i demokratisk livsopfattelse, vor fælles interesse og vort medansvar for at bevare de heraf udsprungne kultur- og samfundsværdier. ${ }^{2}$ Således beskrev Marcussen selv sine bevæggrunde for, at D.U.G. skulle omdøbes til det bredere klingende Dansk-nordisk Ungdomsforbund.

Det er en argumentation, som er helt central for forståelsen af den linje, Marcussen søgte i sit arbejde med D.U.G., Nordisk institut og Folkung-forlaget. Men det er en kendsgerning, at navneskiftet, der for langt størstedelen af D.U.G.s medlemmer var uventet, vakte modvilje $\mathrm{i}$ vide kredse, på trods af at eksempelvis Folkung-bladet allerede fra starten i 1936 søgte den nordiske idé.

Modviljen kom også til at gælde de publikationer, Folkung-forlaget efter april 1940 tilbød foreningens medlemmer. Således beretter Erling Nielsen (formand for Dansk-nordisk Studenterforbund) til Marcussen om misstemningen blandt foreningens medlemmer i Svendborg, efter at Folkung havde udsendt et nordisk orienteret foredrag af P. W. Ryefeldt: I Svendborg var man alt andet end tilfreds med det udsendte skrift, som de nye tillidsmænd havde returneret. "Det er den slags tryksager, der kan bringe Folkung i fare«. Den samme stemning beskrives af tillidsmand Hans Hansen fra Nr. Aaby: "Enkelte tillidsmænd blev fornærmede over det tilsendte "lidt om Norden«, men alt for mange reagerede slet ikke, men lod det lige så roligt blive liggende«.

En sådan holdning var underminerende for foreningen på et tidspunkt, hvor den direkte kontakt til medlemmerne på grund af krigen blev mere og mere sporadisk. Styrkelsen af foreningens nordiske islæt betød, som Knud Fanø udtrykker det i jubilæumsbogen fra 50-året for Det Unge Grænseværn, at det for Marcussen i disse år (1940-45) drejede sig om at »holde en vanskelig opnåelig balance mellem de nære krav i grænselandet og de nordiske fremtidsper- 
spektiver ... «. ${ }^{3}$ En balance, der $i$ det lange løb viste sig umulig at opretholde, på trods af at Marcussen aldrig havde lagt skjul på, at det i langt højere grad var skandinavismen fremfor den danske nationalisme, der skulle være vort skjold mod nazismen.

I hvor udstrakt grad D.U.G.s medlemmer anerkendte Marcussens tanker på dette område, er det vanskeligt at vurdere. I 1954, fire år efter at Marcussen var gået af som formand, vedtoges det at genindføre navnet Det Unge Grænseværn, men foreningen forblev en skygge af, hvad den var i 1930rne. Alt tyder således på, at tanken om et "grænseværn« var til at forstå. Det var en mere eller mindre »tåget« skandinavisme ikke i nær samme grad.

\section{Kontakt til modstandsfolk}

Blandt de mere interessante af Marcussens personlige breve er en række, der knytter sig til redaktør Peter de Hemmer Gudme og stud.mag. Niels Petersens arrestationer $\mathrm{i}$ henholdsvis februar og september 1942. Begge var af D.N.U. flittigt benyttede som foredragsholdere, og begge tog i krigens sidste år aktivt del i udgivelsen af illegale blade.

Niels Petersen ${ }^{4}$ blev arresteret den 24. oktober 1942 efter at have holdt et foredrag for D.N.U. i Allerup på Fyn om forholdene i Norge. Han blev angivet af to personer, der ifølge arrangørerne af mødet blev sat i forbindelse med de danske nationalsocialister fra D.N.S.A.P. Anklagen lød på, at der i Allerup var drevet hetz mod nationalsocialismen og dens repræsentanter $i$ Norge. En "forbrydelse«, der blev takseret til otte måneders fængsel. Omstændighederne omkring Niels Petersens anholdelse og fængsling er grundigt beskrevet i Marcussens breve, der ud over Niels Petersens egen forklaring rummer hele tre uafhængige gengivelser af begivenhederne.

Peter de Hemmer Gudmes anholdelse den 29. september 1942 førte i første omgang ikke til den af tyskerne onskede fængsling. Men da det var givet, at han, så snart han blev sat på fri fod, ville blive taget af tyskerne og ført til Tyskland, gik han på statsadvokatens henstilling med til "Schutzhaft « (frivillig varetægtsfængsling) i 14 dage. $^{5}$. Peter de Hemmer Gudme beskriver i et brev til Marcussen, hvorledes hans sag blev behandlet på højeste niveau mellem de tyske og danske myndigheder. Enden på historien blev et kompromis: Gudme blev ved Højesteret idømt seks måneders hæfte og var således sat ud af spillet, sådan som tyskerne ønskede det. Umiddelbart efter afslutningen af sit fængselsophold i Vestre Fængsel blev Peter de Hemmer Gudme for alvor draget ind i modstandskampen, og som følge heraf blev han atter arresteret i november 1944. Denne gang kostede anholdelsen ham livet. For at undgå at røbe 


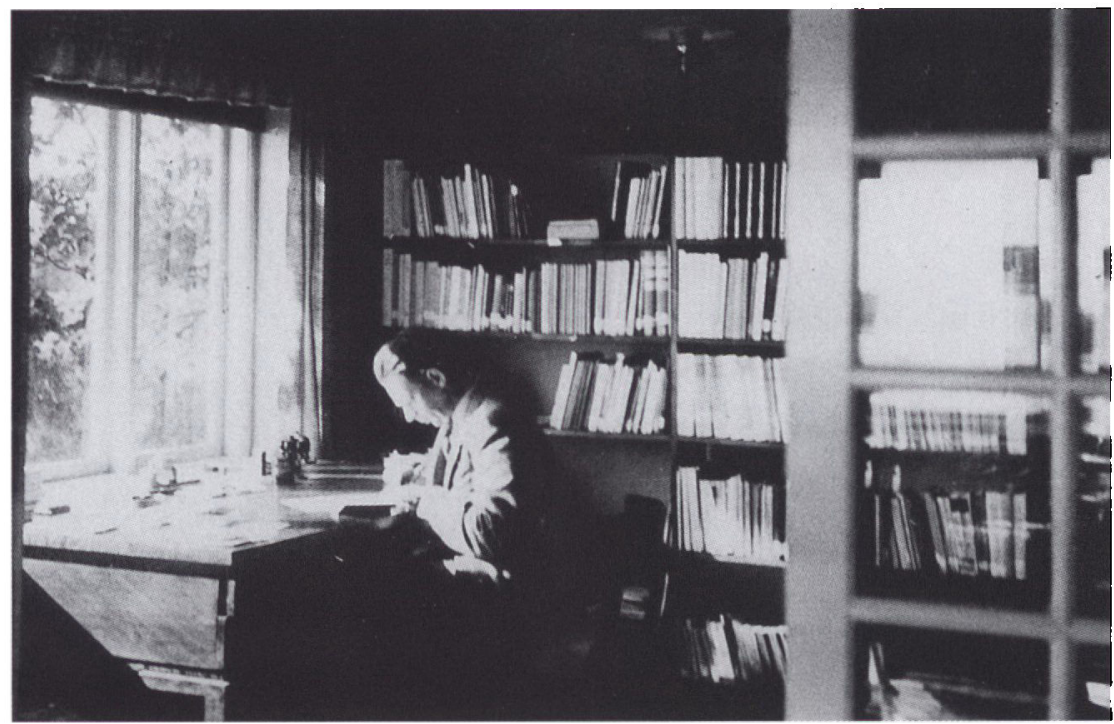

Tyskerne beslaglagde Folkunghus i 1943, hvorefter D.U.G. midlertidigt (1943-48) fik kontor $i$ den lokale roklubs lokaler. Her Marcussen pd sit mnyew kontor i 1943. Privateje.

sine hemmeligheder under tortur kastede han sig på vej til forhørslokalet ud i trappeskakten fra 5. sal i Shellhuset med døden til følge.

\section{Peter Marcussen og illegaliteten}

Peter Marcussen måtte som leder af en organisation, hvis erklærede mål var at bekæmpe nationalsocialismen, regne med at han var i tyskernes søgelys. Han var således blandt de 13 sønderjyder, tyskerne tog som gidsler i forbindelse med overtagelsen af den udøvende magt i Danmark den 29. august 1943. Marcussen blev tilbageholdt indtil den 10. september, hvorefter han kunne vende tilbage til sit arbejde i Gråsten.

En særlig sønderjysk tilbageholdenhed under besættelsen kunne have flere grunde; Marcussen søgte da også at følge en forsigtig kurs over for besættelsesmagten - sådan som han udtrykte det ved D.U.G./D.N.U.'s landsmøde den 5. august 1945: Han ønskede ikke, at D.U.G./D.N.U. som organisation skulle gå ind i modstandsarbejdet, om end det havde været naturligt at styrke dette og vise vejen. Men til trods for, at Marcussen således havde valgt at forholde sig passiv, blev han den 27. juni 1944 arresteret og kom via Frøslev-lejren til koncentrationslejren i Neuengamme, hvorfra han vendte hjem i maj 1945. 


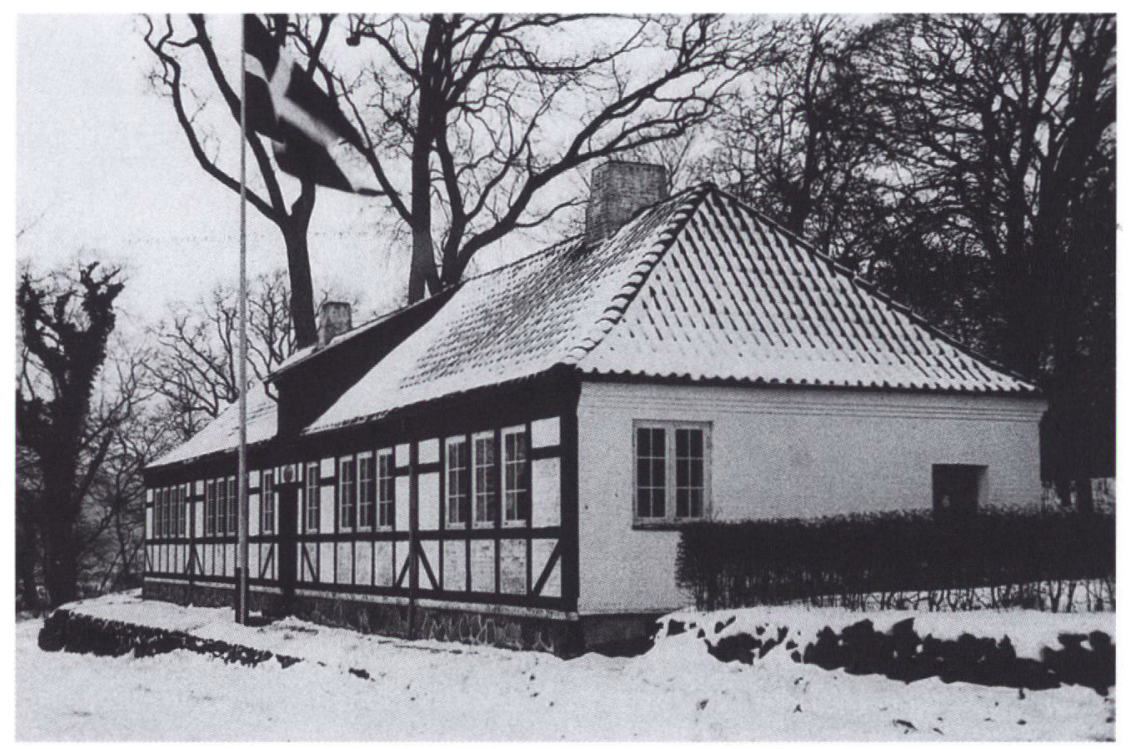

Gransegendarmeriets lenningskontor ved Grdsten Slot. Det var her "Gendarm-Madsen" $i 1944$ gemte sine illegale papirer af vejen $i$ den hule reol. Privateje.

Anklagen mod ham lød på tyskfjendtlig og illegal virksomhed. Baggrunden for anklagen var, at tyskerne under en ransagning af D.U.G.'s kontorer i Gråsten og København havde beslaglagt belastende korrespondance samt udklip fra forbudte svenske blade, altså materiale, hvis lighed med Svennekærgårdpapirerne er slående. Det er derfor fristende at sætte papirerne fra Svennekærgård $\mathrm{i}$ forbindelse med Marcussens anholdelse, men da der blandt papirerne fra Svennekærgård findes illegale tidsskrifter dateret juli og august 1944, holder dette ræsonnement ikke.

Ikke desto mindre er det, på baggrund af hvad der må betragtes som dobbelt held, muligt at løfte sløret for, hvem der tilbage i 1944 gemte Peter Marcussens papirer af vejen. Stadsarkivet i Odense fik efter pressens omtale af Svennekærgård-papirerne en henvendelse fra Kirsten Madsen Hjelmgaard (født Madsen), nu bosiddende i Silkeborg og i perioden fra $1943 \mathrm{og}$ frem til 1950 ansat hos Peter Marcussen på D.U.G.s hovedkontor i Gråsten. Hun kunne berette om, hvordan hendes far, Kresten Madsen (kendt som »Gendarm-Madsen«), der var en nær ven af Peter Marcussen, havde gemt både familiens egne og Marcussens illegale papirer af vejen på »et sikkert sted«. "Gendarm-Madsen« var ansat ved grænsegendarmeriets lønningskontor, hvor han frem til den 19. september 1944, da alle kontorets ansatte blev arresteret af tyskerne, havde benyttet et hemmeligt rum i en reol som depot for illegalt materiale - således også 
Marcussens papirer. Reolen på grænsegendarmeriets lønningskontor ved Gråsten Slot er med sikkerhed identisk med den reol, Poul Jensen fandt på Svennekærgård i 1993.

Men det er et mysterium, hvordan reolen er havnet på Fyn. Dog fortæller Kirsten Madsen Hjelmgaard, at da hendes far efter krigen ville lede efter papirerne, havde det vist sig, at lønningskontoret i krigens sidste år havde været beslaglagt af tyskerne, og i den forbindelse var huset blevet tømt for møbler. Om det er tyskerne, der har ført reolen til Fyn, kan der dog kun gisnes om. Under alle omstændigheder er det et held, at papirerne overhovedet er dukket op igen - og at det har været muligt at fortælle historien bag fundet.

Svennekærgård-papirerne leverer et ret unikt kildemateriale til at belyse aspekter af D.U.G./D.N.U's og dets formands historie i besættelsestiden, en periode, hvorfra kilderne ellers er meget sparsomme. Vi har med dette interessante fund kunnet føje endnu en side til danmarkshistorien, eller for at bruge Poul Hammerichs velvalgte ord: Hevet den ud af den største af alle historiebøger, nemlig glemmebogen.

\section{LITTERATUR}

Det Unge Grænseværns årbøger: Diverse årgange.

Knud Fane m.fl.: Det Unge Grænseværn. DUG, Senderborg, 1983.

Troels Fink: Sønderjylland siden Genforeningen i 1920, 1955.

Folkung-bladet: Diverse årgange.

\section{UTRYKTE KILDER}

Det Unge Grænseværns forhandlingsprotokoller. Venligst udlånt af Sv. A. Hellesen, Sønderborg (senere overført til Landsarkivet for Sønderjylland)

Landsarkivet for Sonderjylland:

Det unge Grænseværns arkiv Acc. nr. 23.

Graasten Kommunes Lokalhistoriske Arkiv:

Peter Marcussens arkiv.

Stadsarkivet i Odense:

Interview med Kirsten Madsen Hjelmgård (født Madsen).

\section{NOTER OG HENVISNINGER}

1. Tallene stammer dels fra foreningens forhandlingsprotokoller og dels fra foreningens årsberetninger. For oversigt over foreningens medlemstal se Knud Fanø: «Det Unge Grænseværn«, 1983, s. 174.

2. I et brev til historikeren Aage Trommer dateret den 3. december 1964 gør Peter Marcussen rede 
for baggrunden for, hvorfor D.U.G./D.N.U. orienterede sig så stærkt nordisk. Landsarkivet for Sønderjylland: Peter Marcussens arkiv.

3. Knud Fanø m.fl.: Det Unge Grænseværn. DUG, Sønderborg, 1983, s. 190.

4. Niels Petersen, arkivar i Rigsarkivet, 1922-96, se Magda Dalgård: Personale i Rigsarkivet og landsarkiverne, Rigsarkivet 1980 s. 16.

5. Dansk Biografisk Leksikon, bd. 5, s. 372-73. 